\title{
Como conchas à beira-mar: fragmentos de vida
}

\author{
Like sea chells: fragments of life
}

\author{
Kamila Vilela de Souza; Leila A. Domingues Machado \\ Universidade Federal do Espírito Santo
}

\begin{abstract}
RESUMO:
Andamos pela cidade, tomamos um café na varanda, conhecemos vidas que a sociedade tentou apagar. Vidas marcadas por internações manicomiais e que foram durante muitos anos caladas. Durante encontros semanais em uma casa na cidade de Cariacica - ES, conversamos com alguns senhores e em alguns momentos escutamos histórias de vida, geralmente narrativas fragmentadas feitas de vestígios e, nesse trabalho, contamo-las: são nossas conchas. Amadoramente fotografamos pedaços, restos e expressões. Compomo-nos junto, nos misturamos e sentimos. Aqui são apresentadas poucas palavras que narram vidas, que narram histórias, que narram o cotidiano. Habitamos essa casa, mas também caminhamos, pois entendemos a cidade como lugar de potência, de criação e de desconstrução - somos andarilhos da beira da praia. Sim, a praia, mais precisamente a água nos acompanhará nesse percurso. As ondas nos guiam, o mar nos fortalece, a areia nos tira do conforto.
\end{abstract}

Palavras-chave: loucura; narrativa; cidade; clínica.

\section{ABSTRACT:}

We walk through the city, have a coffee on the balcony, meet lives that Society has tried to erase. Lives marked by manicomial hospitalizations and which have been silenced for many years. During weekly meetings in a house in the city of Cariacica - ES we talked to some gentlemen and in some moments, listened to their life stories, generally fragmented narratives made of vestiges and in this text, we narrate them: they are our shells. Amateurishly we photograph pieces, rests, and expressions. We compose together, we mix and we fell. Here we present a few words that narrates lives, which narrates histories, which narrate the everyday. We inhabited this house, but we also walked, because we understand the city as a place of potency, of creation and deconstruction - we are walkers along the beach. Yes, the beach, but precisely the water that followed us in this journey. The waves guide us, the sea strengthens us, the sand takes us from comfort.

Key-words: madness; narrative; city; clinic.

DOI: 10.12957/mnemosine.2020.52699

Andamos pela cidade, tomamos um café na varanda, conhecemos vidas que a sociedade tentou apagar. Vidas marcadas por internações manicomiais e que foram durante muitos anos caladas.

Toda quinta-feira, às 13h, nós, integrantes do Laboratório de Imagens da Subjetividade (LIS) - coletivo de estudos e supervisões sob a orientação da Prof. ${ }^{a}$ Dr. ${ }^{a}$ 
Leila Domingues Machado, vinculado ao Programa de Pós-Graduação em Psicologia Institucional da Universidade Federal do Espírito Santo (PPGPSI/UFES) -, vamos a uma residência terapêutica (RT) localizada em Santana, Cariacica- ES, e lá passamos nossa tarde.

Essa casa tem oito (às vezes sete, às vezes seis) moradores do sexo masculino que tiveram a vida marcada por internações psiquiátricas, e junto a esses senhores nossa pesquisa se desenvolve. Com eles conversamos, passeamos, jogamos, ou ficamos apenas em silêncio. Com eles, nos colocamos a escutar e a recolher fragmentos de histórias de vida: são nossas conchas! Conversamos durante nossas andanças pelo bairro, sentados na praça, conversamos durante o café, sentados na beira da cama e onde mais a conversa surgir, onde o silêncio se desfaz ou onde o corpo convoca.

São vidas escondidas pela poeira do esquecimento. Histórias caladas, dissecadas e marcadas pelo anonimato e pela inexpressão. Vidas que foram contadas por outras vozes, reinventadas.

Amadoramente fotografamos pedaços, restos e expressões. $\mathrm{O}$ ama(dor) não tem pretensões, não tem obrigações, não tem regras pré-estabelecidas. Algo se passa e convoca ao registro. São fotos imaturas de momentos comuns. Um olhar para essas existências infames, um corpo que se mistura ao outro.

Assim como essas imagens, as histórias também nos convocam. Escutamos histórias como catamos conchas na beira da praia. Não perguntamos, não entrevistamos, não confrontamos. Não exploramos esse mar, não peneiramos a areia em busca dessas formações. Apenas tivemos um olhar e uma escuta atenta ao que se passava. Narradorsucateiro. Nossa aposta foi na espera, na escuta e na paciência de que essas histórias surgiriam. Escutar é diferente de fazer falar. Caminhemos.

\section{Chegando à Ilha}

A ilha onde ancoramos nos exige engajamento e habitação em um território que nos era desconhecido. É preciso se permitir transformar e transformar-se, estar aberto ao encontro com o outro e acompanhar movimentos: movimento da vida, movimento de vida. Não existem distanciamentos e neutralidades, o que existe são composições mútuas e em constante mutação. É preciso perceber ritmos, sabores e afetos. É preciso desconstrução, desnaturalização e inventividade. Não há regras a serem seguidas, não há teorias a serem comprovadas, não há caminhos pré-fixados e nem a certeza de chegada a algum fim. Nossa ilha exige apenas sensibilidade. As ondas vão nos guiando, o vento 
nos conduz, não na forma de náufragos, mas como exploradores de possibilidades. Aprendiz-cartógrafo. Aprendiz de marinheiro.

Nosso caminho é longo, com muitas árvores, buracos e gente. Gente de todo tipo: gente trabalhando, gente brigando, gente vagueando, gente orando, gente brincando, gente vivendo, gente sobrevivendo. Buracos que surgem, buracos em que caímos, buracos em que escolhemos cair. Poeira, muita poeira. E há cabras também, quase tão conhecidas como se fossem de estimação. Caminhos que não sabemos bem o fim, na verdade não sabemos nem como começou, mas estamos na estrada, no descobrir. Caminho que é seguido por discussões acadêmicas e por silêncio, por vida e por captura. Polícia, bombeiro, mecânica e padaria, muitas padarias. Igrejas não podem faltar, são muitas, todas em movimento. Parecem brotar a cada semana. Muitas casas, muito verde, muitos animais. Muita potência de vida, ela pulsa.

$\mathrm{Na}$ primeira ilha tínhamos alguns dispositivos bem interessantes: um terraço e uma escada. Eram mediadores de histórias, propiciavam ambiente para escutarmos e para trocarmos histórias de vida. Momentos antes e após o café eram os mais produtivos - afinal, quem não gosta de uma prosa ao cheiro de um cafezinho?

Desde o primeiro contato com esse campo que se apresenta e urge a ser escutado, tem algo que me chamou muita atenção e me causa grande incômodo: o portão aberto e ninguém na rua, ninguém sai, ninguém... Conseguimos no primeiro dia no campo dar uma volta aos arredores da casa, mas depois de muita insistência e depois que o morador ficou certificado que todos iam. Não sabia nem por onde começar, se ia para lá, se ia para cá, e enfim tomou sua decisão. Andamos pelas ruas, tiramos fotos, sentamos na murada da igreja e ficamos lá imaginando o dia que uma bela explosão acabaria com um grande santuário manicomial que logo ali perto se mostrava. Ouvimos os vendedores de rua com sua cavalinha e outras promoções. Os cachorros nos seguiam e andávamos sem pressa e sem rumo. Às 15 horas o cheiro do café nos alcançou e voltamos para casa. No terraço, o ar fresco batia e ao olhar para o horizonte conversávamos sobre a vida.

Nesta primeira ancoragem na nova ilha, conheci um sorriso, um sorriso dos dentes podres, um sorriso que acolheu e ofereceu rota:

Enquanto fumava seu cigarro em uma convidativa escada, conversávamos sobre Narrativas e Biografemas. O que nossa inocência (?) não contava é que ele não só entendeu os conceitos, como propôs um terceiro: "Tela, como uma novela com várias histórias e que ninguém sabe o fim” (Diário de Bordo. 04 de maio de 2017). 
E seguindo essa pista, nossa proposta é de escutar, recolher fragmentos e fazer ressoar vozes, vozes essas caladas, deslegitimadas. Os fragmentos incomodam, representam incompletude, podem ser apenas cacos de um discurso, porém, "raspas e restos me interessam" (BARÃO VERMELHO, 1984), rastros também. Vestígios, fragmentos, estilhaços.

Escrita por pedacinhos, escrita curta, "gostando de encontrar, de escrever começos, ele tende a multiplicar esse prazer: eis por que ele escreve fragmentos: tantos fragmentos, tantos começos, tantos prazeres” (BARTHES, 1977: 101). Escrita em fragmentos que não pretendem dar conta de contar toda uma vida, não pretende ser cronológica, fidedigna, tampouco linear e sequencial. O "germe do fragmento" (BARTHES, 1977: 101) (por que não germe do pensamento?) pode surgir em alguma conversa aleatória, nas andanças pela cidade, durante um café ou após o mergulho no mar. Cada pedacinho é uma obra, cada concha se basta. "O não acabamento de uma vida é o grande legado que uma biografia pode oferecer" (COSTA, 2010: 48).

Algumas semanas após esse encontro, a residência que nos recebe mudou de lugar, uma mudança um tanto rápida, sem avisos, sem preparo, sem escolha. Um dia no anoitecer os moradores saem sem saber ao certo o novo rumo. Nós também somos pegos de surpresa. Surpresa ao ver (ou ao não ver) uma frondosa mangueira do vizinho agora inexistente e surpresa ao ver portas e correntes bem trancados, parece que muita coisa mudou em uma semana... e fomos nós, três navegadores à deriva e na busca pela ilha que parece que foi engolida por uma onda e simplesmente não estava mais ali. Fomos levados pela maré, morro acima, morro abaixo, vira na padaria, não essa, a outra padaria, ainda não essa, mais à frente, não, ainda não é essa rua do beijo, é outra rua do beijo... e após alguns caixotes e um cuidado para não nos afogarmos ou não deixar nos afogarem, achamos a nova ilha! Uma ilha com muitas árvores, pássaros, cachorros e vizinhos. Temos uma praça! Vemos novos dispositivos: andanças pelas ruas, varanda improvisada, área de serviço fresca, e não podia faltar: a mesa do café! E vamos à nossa caminhada nos compondo e explorando novos cheiros e novos ritmos. Mas um detalhe não passou despercebido: apesar da mudança potencializar muitas coisas, a nova casa está ainda mais perto do antigo manicômio. Espero que seja apenas um detalhe que meus olhos maliciaram, espero. 
A hora do café continua ser um momento que nos convida a nos demorarmos nos detalhes: está na hora em que se encerra o Vídeo Show e começa a Sessão da Tarde. Sempre nos surpreendemos com o filme! Parece que o tempo ali não passou, o mesmo filme que assistimos na infância continua a ser reprisado. A história sempre se repete, não se atualiza. Sentamos na sala e é interessante observar o movimento, todos os moradores sentam-se à mesa posta. Quem está mais perto da bandeja serve quem está mais longe antes mesmo de pegar. Comem e levam as louças para a cozinha, agradecem, pegam mais café e quem fuma vai fazer seu rolo. Na varanda improvisada fumam o cigarro tão esperado após a refeição. Também não se incomodam de dividir, repartem com quem na teoria não pode fumar. Ainda sentados na sala diante de uma estante, que tem apenas um calendário parado em março e nosso conhecido jogo de dama encostada em uma parede repleta de pássaros a voar. Vemos o sorriso transitando com a vassoura e pá para catar as pontas no chão. O movimento parece ritmado e se repete toda semana.

Seguimos como nossas andanças, quase sempre acompanhados pelo sorriso. Parecia cada vez mais familiarizado com os caminhos, nos mostra outras residências bem próximas e já escolhe o caminho sem tanta vacilação. Sentamos na praça, vemos crianças brincando, cachorros se coçando, pão saindo quentinho, vemos vida em movimento. Ao longe vemos uma grande planície onde meninos jogam bola, mas não devemos ir até lá "vai que tem polícia", mas ficamos ao longe admirando a bela paisagem. Nos caminhos vemos outra residência terapêutica, mas nem podemos pensar em chegar perto de lá, um sorriso vermelho e tímido se apresenta ao contar quem mora do outro lado: "só mulher". E assim seguimos, sem rumo, sem regras, apenas andando e escutando - escutando pássaros, escutando crianças ao longe, escutando vida, escutando o silêncio. Aprendemos (juntos) a surfar.

Outras tardes, outras andanças, novas companhias. Uma tarde fresca pelas ruas da vizinhança vemos pássaros, cachorros arredios e as árvores não tão frondosas, mas bem convidativas. Um sentimento de liberdade e de angústia: por que não fazem mais isso? Um bairro tranquilo e de muito moradores, onde podemos andar no meio da rua sem medo de carros ou de outros perigos, livre para andar, para correr, para sentar, mas aprisionados por uma lógica que dói de ser percebida. É a ilustração real do poder disciplinar (FOUCAULT, 2006): a vigilância, o controle já está naturalizado como uma norma, como um hábito. São corpos sujeitados, fabricados por esse poder. O portão aberto e a prisão mental. Há tanta potência pelas ruas, há tanta potência no encontro 
com o outro, há tanta vida, tanta arte, tanto bicho, flores e pixos. Várias moradias com histórias que se perpassam tão perto fisicamente, mas tão afastadas. A vontade é de abrir todos os cadeados e amarras e de fazer um grande encontro na praça ao som de uma moda de viola.

Ando seguindo os passos, mas a vontade é de arrebentar as correntes. Entre os passos trôpegos um lixo e outro se apresentam, são pegos, observados, cheirados e jogados novamente. Catam-se plantas, matos do meio fio, cheiram-se rosas. Um caminhar sem rumo, sem intenção, sem procura, mas de encontro, de encontro com o verde, de encontro com um igual - igual que deve ser separado por paredes, afinal, existem regras - encontro com a dúvida, com a incerteza, com a busca e quase um resgate a beira de uma subida. Encontro com a senhora que varre a calçada ou com o moço que passa com o frete. Encontro com histórias de não amores nas paredes e de frutas apetitosas e azedas: tão azedas como o resultado do mal-me-quer das flores, mas tão apetitosas quanto a vida que pulsa nas ruas da cidade, tão apetitosa quando o cheiro do café às 3. Azedo e apetitoso é também o silêncio que se faz presente, que corta, um silêncio que de incômodo passa a ser de reflexão. Corpos nada sincronizados que se permitem, que sentem, que se afetam. Também há rosas, rosas que perfumam esse ambiente e que envaidecem, que representam afeto e demonstram vínculo. Fragilidade. Força.

Novas companhias continuam a surgir, uma companhia dos passos largos e apressados. Me faz acelerar, me tira do lugar de conforto. Segue com o olhar, espera. Corre. Segue de mão dada - precisa de companhia, não de segurança e nem de tutela. Sabe para onde quer ir, mostra firmeza, e ai de mim se não acompanhar, fico para trás. Com esse passo exploramos novos lugares, novas subidas e becos. Novas flores, novas frutas, novos cachorros de rua, novos ares. Com esses passos que se perdem nas horas, uma nova companhia nos encontra: é preciso voltar, está na hora do remédio. A companhia que nos encontra gosta de caminhar sozinho e pela manhã logo após o café. É bom vê-lo por aqui.

Outros passos também só caminham sozinhos, sentam lá na estrada para ver os carros passarem, sentam na praça para ver os moleques correndo, dão voltas e mais voltas na praça. É um "não" saboroso que recebemos quando não querem caminhar conosco, e vão sozinhos. É um "não" de autonomia, de pontuar qual é o espaço 
permitido de se chegar. É um "não" de não assujeitamento. Adoramos companhia, mas um "não” também é maravilhoso!

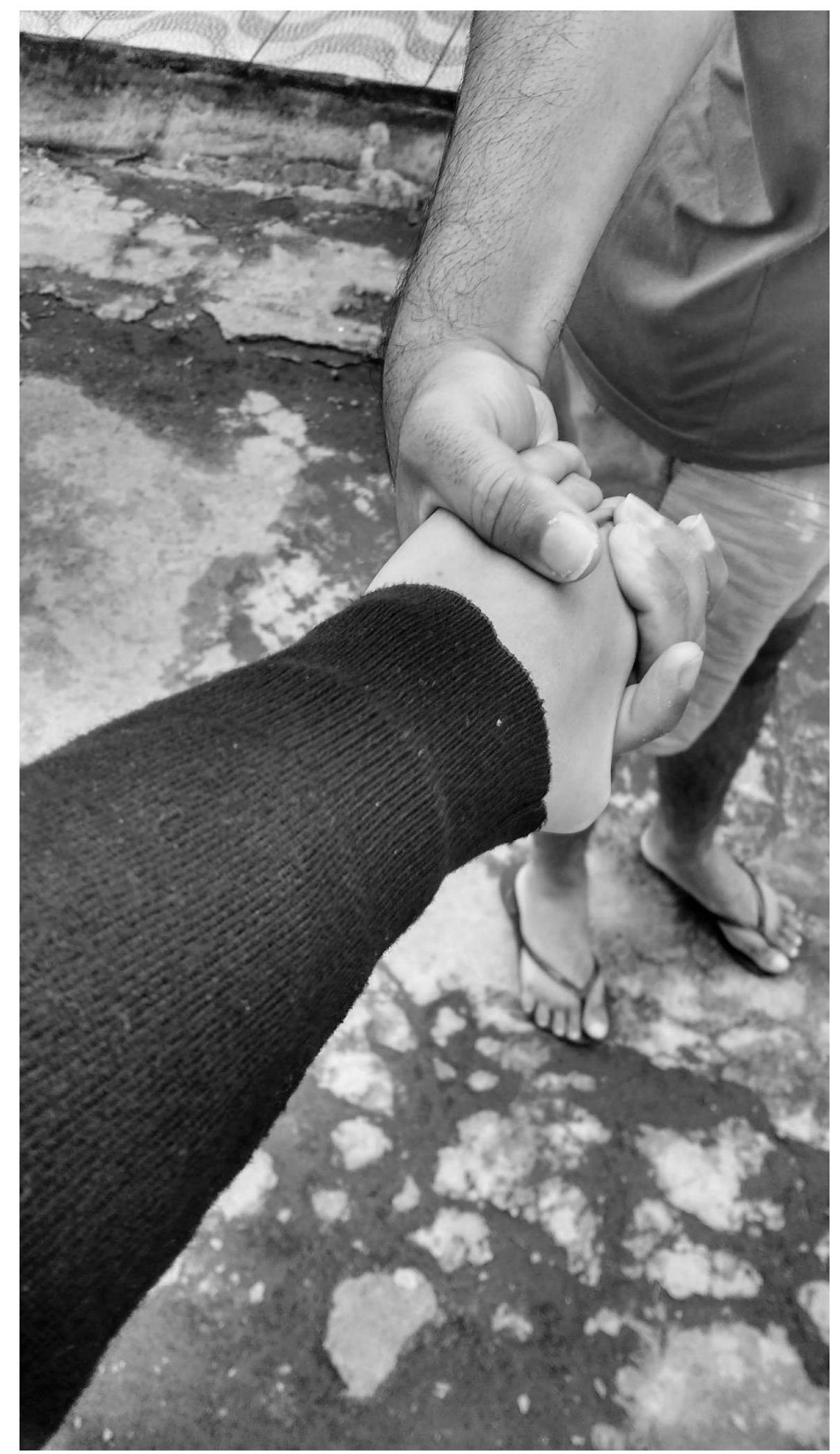

Mãos dadas 
“Deve-se realmente caminhar sozinho?" - questiona Gros (2010: 59). "Quando acompanhado, esbarra-se, atravanca-se, perde-se o compasso. Porque é disso que se trata, ao caminhar, de encontrar seu ritmo básico e de mantê-lo. (...) Mais de quatro é uma colônia, um exército em marcha”. Nem por isso é imprescindível a solidão. Podese caminhar só algumas pessoas, cada um no seu passo, algum na frente, outro mais atrás, uma troca de olhares para saber se estão todos bem, diminui-se o passo, espera o parceiro. Ritmos se alteram, se esperam, se cruzam. Solidão compartilhada "porque também se divide a solidão, tanto quanto o pão e o dia" (GROS, 2010: 60).

"Vamos dar uma volta?" - é uma pergunta habitual. Saímos da estagnação das paredes e seguimos pelas ruelas. Caminhamos calados sentindo a brisa, caminhamos pensando e percebendo as cores, os cheiros. Sentimos as paredes pintadas, a nova horta que surgiu. Sentimos o quadro católico. Sentimos a fumaça dos carros e a moto que passa acelerada. Quando caminhamos pela cidade, o fardo do dia a dia se perde, esquecemos compromissos, preocupação, rancores. Às vezes esses nos acham no portão durante o retorno...

As lembranças funcionam como um fardo, um peso nas costas que pode atrapalhar a caminhada (GROS, 2010). Mas durante o perambular com o ritmo próprio, por vezes irregular, o corpo avança: o que permite à mente descansar das cargas da vida. Escapa-se do peso, vêm então as ideias. Entoam-se histórias.

Nossas caminhadas quase nunca têm rumo. A vontade é o destino. Apenas vagueamos pelas ruas próximas, trocamos bom dia com algum vizinho que experimentou se aproximar. Os caminhos são conhecidos, percursos marcados que se repetem. Por escolha, ou por falta dela. Não há nada de exótico ou sublime, apenas o que é habitual, real, sujo. Caminhar é monótono. Como diz Gros (2010): é a monotonia contra o tédio. Tédio enquanto imobilidade, cansaço, inércia. Na caminhada sempre há algo: a própria caminhada, um pé na frente do outro e seguimos. Avante!

Gros (2010) defende que caminhar, além de um passeio, é um ato político. Caminhar fazendo-se andarilho, sem andar apressado, deixando-se, assim, encontrar pelos acontecimentos. Não buscamos caminhos, mas os descaminhos. Tornando a paisagem como moradia; as ruas, os buracos, o asfalto como velhos conhecidos: saída para fazer-lhes uma visita. Dessa forma, nunca se está sozinho ao caminhar.

No decorrer dos meses, as coisas mudaram: quase todos os moradores "podem" sair. Alguns só saem sob vigilância e desconfiança, "vai fugir" é a mordaça da vez. 
Medo de fugas. Que fuga? Fuga de onde? Afinal, a casa não é deles? Logo, não poderiam sair, passear? Não. Portão fechado, chave escondida em prol de proteção. Proteção contra quem? Contra o quê? Tutela. Lógica manicomial. Aprisionamento. Cuidado?

A maioria dos moradores tem livre acesso à rua, é só pedir para sair. Pedir. Mas a casa não é deles? Alguns continuam a andar sozinhos, mas aceitam nossa companhia. Por diversas vezes vamos todos juntos dar voltas pelo bairro. E para outros passeios, é só avisar? É só pedir? Também não. Um simples passeio demorou meses para se efetivar. Burocracia. Medo. Cuidado.

Cuidado?

Outra mudança. A casa feminina não estava bem adaptada. Era uma casa com escada, no pico de uma subida íngreme e onde faltava muita água. A solução? Trocar de casa com os homens. Mais uma respirada profunda para ter certeza de que não nos faltará o ar. Encher os pulmões, armazenar vida. Não temos mais uma praça, não temos mais o campo, os cachorros são outros e não há outras RTs por perto. O espaço externo mais agradável é um bar que fica fechado durante o dia. Trocamos nossas árvores frutíferas por promoções de Devassa. Nosso caminhar pela cidade ficou bem mais restrito, começando pelo portão, sempre trancado. Não tem muitos caminhos: ou vamos para a rua de trás e sentamos na mureta, ou vamos andar por trás do condomínio, um caminho deserto e de olhares não acolhedores. As outras ruas são subidas ou descidas bem íngremes.

Fomos convidados a tomar um café da tarde em outra residência ali próxima. A casa tem cheirinho de pão, frescor e belos sorrisos nos acolhendo. Oito moradores bons anfitriões. Entre abraços e cafés, um grande painel me chamou atenção: aquelas fotos com Papai Noel no shopping e o papai em questão com uma cara de poucos amigos... Fiquei imaginando a cena - trocaram crianças por um bando de doidos... Imagine o tempo que levaram para que todos olhassem ao mesmo tempo para a câmera e fossem capturados por um click. Será que não foram bons meninos durante o ano e Papai Noel queria deixá-los de castigo sem presente? Será que já não ficaram de castigo por alguma arte que nem sabem qual durante tantos anos? Será que já não passou do momento do presente ser realmente menos oneroso? A captura não foi somente de quem estava em cena, foi minha. Olhei, pensei e ri. 
Pensei na desconstrução que eles causaram no Papai Noel, na discussão que desencadearam nas famílias das crianças ali presentes, que provavelmente pediram uma explicação aos pais temerosos. Pensei nos seguranças no shopping e seus olhares. Pensei na felicidade desses moradores com o novo passeio. Pensei no Natal e suas músicas que agora parecem ironias. Será que tiveram alguma "Noite Feliz"? Penso que a legenda dessa foto poderia ser: "Quero ver o amor crescer, mas se a dor nascer você resistir e sorrir...", e essa história de que "Seja rico ou seja pobre, o velhinho sempre vem"? Talvez até venha se formos até ele, mas será que é um desejo real do velhinho estar ali? Não me pareceu muito acolhedor. Penso que nunca mais vou ver o Natal com os mesmos olhos...

Falando em comemorações de fim de ano, me remeto ao Natal na casa que nos recebe. Fizemos um lanche especial no Natal. Levamos panetone, biscoito e refrigerante. Eles não pediram nada, foi uma demanda nossa marcar essa data de alguma forma. Pareceu ser uma data qualquer. Não falaram da família, não falaram de nada. Não transpareciam tristeza pela data, o que compartilhamos com outros moradores em outros momentos. O assunto de voltar para casa sempre surge, mas dessa vez não. Conversando com uma amiga muito sensível, ela fala sobre a ferrugem e como o manicômio produz vidas enferrujadas, no sentindo de estagnação, desinteresse talvez, mas esse sendo produzido pela não oportunização desses momentos. Precisamos por vezes ser o óleo dessa engrenagem, desenferrujar essas vidas, mostrar que é possível, e a partir daí oportunizar escolhas, criando modos de produzir desejos. Arrumamos a mesa e dentre sorrisos comemos e conversamos. Escutamos algumas músicas que eles foram pedindo e senti naquele momento que estávamos felizes. Mas algo cortou e silenciou: "Parem de comer como se estivesses passando fome. Daqui a pouco vão cagar pelas pernas." Caldo. Embargo. 


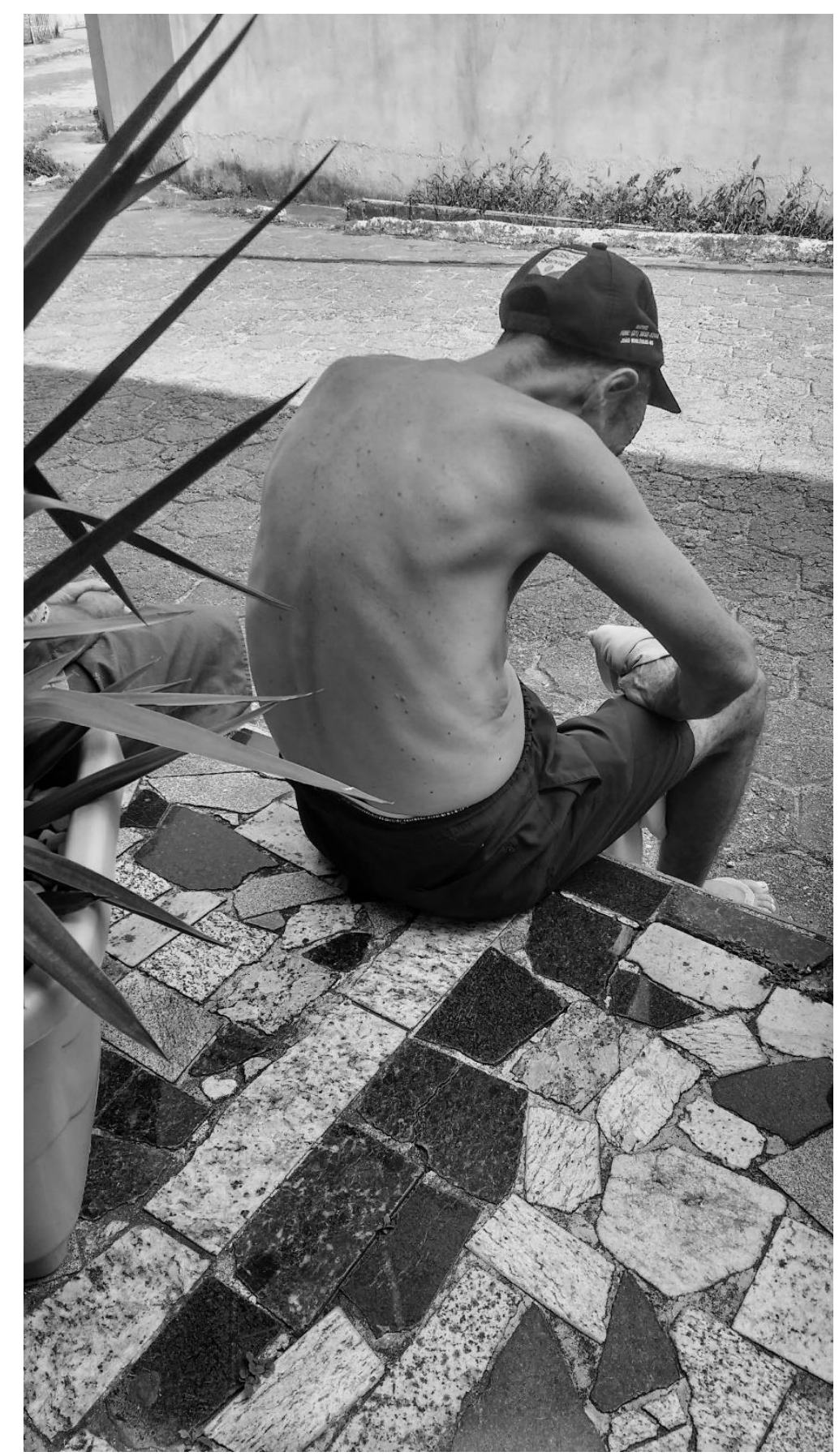

Sentados na rua

Não só de convites fazemos nossas paradas. Resolvemos nos convidar a um café em uma casa feminina. Fomos em 6 apertadinhos em um carro. Um aperto que aquecia o coração, um aperto de expectativas, um aperto quase como um abraço. Em uma sala ampla nos aconchegamos e fomos apresentados. Uma e outra moradora passava, falava 
algo e ia continuar sua rotina, algumas não pareceram muito confortáveis ao serem acordadas para nos receberem. Mas uma senhora em especial me laçou: ela sorria, oferecia água, oferecia o lugar, mas mais do que isso, ela oferecia a mão, oferecia um afago, oferecia o sorriso. Ela oferecia histórias de vida, ela oferecia experiência. Como poucas vezes me senti realmente em sua casa, não um serviço ou uma hospedaria, mas tinha algo ali de marca, de afeto, de posse. Combinamos outros cafés, em outras casas, em outras ilhas. Novos encontros. Novo.

Voltamos nessa casa em alguns outros momentos, um café aqui, outro café lá. Conversas começaram a surgir, catamos conchas.

Soubemos durante uma conversa de uma data de aniversário. Começamos a perguntar as demais datas superanimados de comemorarmos esses eventos! Sim, a animação não era exatamente dos moradores... Nem todos sabiam ou queriam comemorar o aniversário. Conversamos sobre isso, e a vontade de não ter uma data de aniversário foi respeitada. É preciso ter sensibilidade para sentir esses fluxos. Esperar. Escolher. Porém, nesse processo muitas coisas nos surpreenderam. Começando pelas datas. Alguns não sabiam, diziam ter esquecido, pois a data de nascimento nunca teve importância. Nunca foi lembrada, nunca foi comemorada e tampouco sentida. A percepção dos anos vem através do corpo. O corpo está mais cansado, a vista turva, a saúde debilitada. Vamos ver então a data no documento! Mas que documento? Eles não os têm. Se existe, fica em posse de alguém que não os mesmos. Descobrimos então o Cartão SUS de alguns senhores guardados (ou escondidos/esquecidos?) em uma gaveta da cozinha. Essa gaveta é a protegida. Lá é onde as chaves ficam guardadas (ou escondidas?), e os remédios ficam separados. Cada morador tem vários saquinhos transparentes. Em cada saquinhos tem cerca de 3 a 5 comprimidos que eles tomam $3 \mathrm{x}$ ao dia mais ou menos. Ou seja, 3 saquinhos para cada morador, o que no dia são aproximadamente 10 a 15 comprimidos para cada. Nisso não há dúvida, está bem nítido.

Fomos olhando os cartões enquanto uma cuidadora chamava-os para entregar a medicação. As datas são as mesmas: 31 de dezembro. Todos nasceram no mesmo dia? Que nascimento foi esse? Uma nova vida após o manicômio estava traçada. Ano novo, esperança de melhoras, esperança que o novo nos surpreenda, início de um novo ciclo... Tantas significações e esperanças renovadas são representadas em uma virada de ano. Ficam apenas questionamentos que nunca terão uma resposta: Por que essa data? Eles 
não sabiam as datas oficiais? Não tinha como saber? Não tinha como resgatar essa documentação, uma segunda via que fosse?

Novas surpresas: “Quem é João?”. Resposta? “É o Antônio”. Isso mesmo. Nem os nomes são os deles. A história parece ser assim com quase todos os moradores: um dia qualquer, andando pelas ruas, catando algo para vender ou pedindo comida, eles foram "convidados" a sair da rua, e ir para o manicômio. Lá tiveram um novo nome e uma nova data. Um registro foi criado. Ano Novo? Desaparecendo, dissolvendo, desfazendo... Apagaram a história. Tentaram. Quando se entra no manicômio, o velho homem fica para fora, ele some da sociedade e uma nova identidade é forjada. É necessário achar uma identificação outra que não aquela prévia. Morte.

Morre o sujeito, desaparecem suas características, suas marcas, sua biografia. Despistado dos seus signos, da sua individualidade. Apagamento involuntário.

Os nomes com que os conhecemos foram inventados. Após tantos anos, essa identidade cola na vida do dia a dia. Cola de forma primária, aquela colagem cheia de dobra e dedos sujos que ficaram marcados. Cola que calou, mas que não passou despercebida. Deixaram os rastros pingarem no chão. O cartão SUS estava ali. Os saquinhos também. Eles tinham nomes outros que não conhecíamos. Assim como não conhecíamos os sujeitos daquelas medicações. Que tanta brutalidade, agitação e perturbação são essas que precisavam ter essa camisa de força química? Fica aqui outro questionamento sem resposta.

Situações que nos exigiam um olhar mais cuidadoso também nos passavam. Um dia qualquer resolvemos caminhar por novos caminhos. Fomos andando, vendo as plantações de uma horta vizinha: couve, cebolinha e um matinho que ninguém sabia se era rúcula, espinafre ou mostarda. Novas subidas, novas descidas, novos buracos e novos comércios. Um colega de caminhada a cumprimentar, uma criança a sorrir, um cão a abanar. Ruas estreitas que tinham que ser divididas com carros, vassouras e banners. Risos, conversas e um empurrão: “Eu vou fugir!” Segundos de paralisia para entender o que aconteceu e consolo de um outro morador: "Ele é maluco, sempre foge e quando passa fome ele volta. Pelo menos agora o portão vai ficar aberto!” Fuga. Essa palavra não me desce, mas me escapa. Parece algo que não consegue ser digerido, mas está pronto para sair. Considero essa palavra extremamente manicomial. Afinal, a casa não é dele? Por que fugir? Pode ter ido dar um passeio, ter ido visitar a família que ele acredita estar à sua espera. Mas todo um sentimento de culpabilização, de tutela passa 
pelo corpo. As histórias de sua família que soubemos há pouco conseguem ganhar espaço. Tenta gritar.

Na semana seguinte, de um corpo sem-vergonha, tenho um corpo receoso: a cada olhar penetrante, um corpo que tenta se esquivar. Ou se esquiva, se percebe e tenta retomar. Uma verdadeira batalha interna para não deixar um muro de desconfiança se instalar. Um pedido de desculpa, um pedido para nova saída e um alívio: está chovendo! Junto a isso, falas que aparecem na casa e precisam ser rebatidas, conversadas. De um corpo que se esquiva para um corpo que defende, que não se aceita manicomial. Ressaca de emoções se movimentam em silêncio. Reconstrução de vínculo, percepção de si.

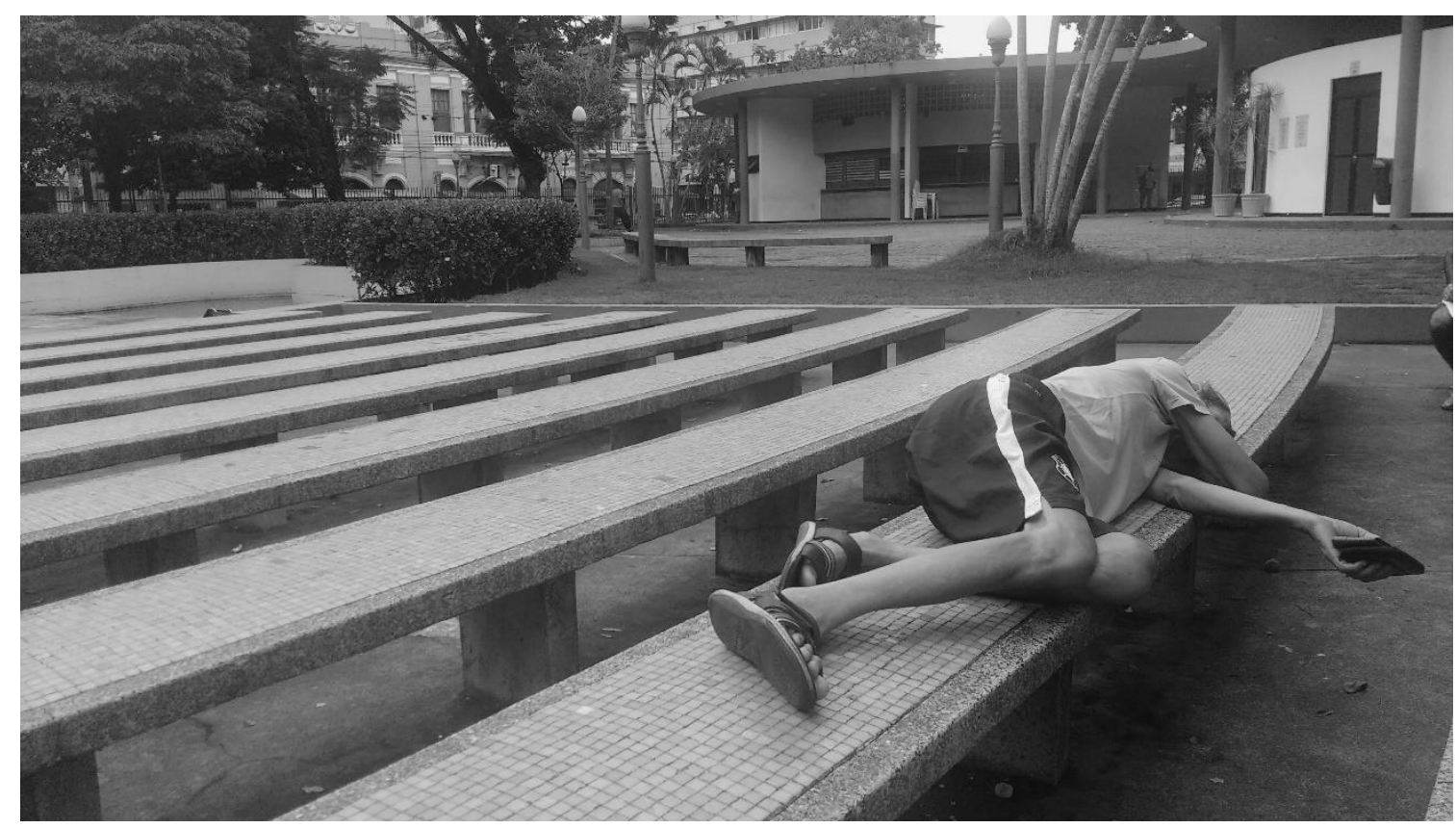

\section{Banco da praça}

Pelbart (2000: 45) nos traz a cidade, as ruas com nossas andanças, como um lugar de fonte inesgotável de detalhes para se explorar, surpresas e personagens, onde é possível perder referências e a si mesmo, sendo dessa forma uma imagem do desejo com seus rastros e ruínas: o lugar do possível. Interroguemo-nos: "que afetos ela favorece ou bloqueia, que trajetos ela produz ou captura, que devires ela libera ou sufoca, que forças ela aglutina ou esparze, que acontecimentos ela engrena, que potências fremem nela e a espera de quais novos agenciamentos”. 
Cidade como lugar de possibilidades. Cidade-rede, cidade-fluxo, cidade-maré. Em complemento, Silva (2005) considera a rua como um dispositivo, no sentido de rede/campo de forças, onde há produção do novo, onde há rotas de fuga de um funcionamento cronificado. Na rua, na cidade, é possível a criação e constantes mudanças de todos que se envolvem e se afetam no contexto urbano.

Benjamin (1995) nos alerta que orientar-se na cidade não significa muito; é importante deixar-se ir, deixar a cidade guiar, as ruas convidarem. É preciso fazer-se andarilho, fazer-se navegador, ter um "corpo errante à deriva" (MIZOGUCHI, 2012: 57). É preciso "viver no mundo como quem enfrenta o mar aberto a nado. Passar do ponto em que não se é capaz de retornar à terra firme, criar corpo para sustentar a travessia" (BAPTISTA E SILVA, 2017: 65). Enfrentar o mar aberto a nado: exige entrega, exige confiança, e mais do que isso, exige um corpo que se funde de tal forma que não é possível mais retornar, retomar o que se era antes. O corpo precisa da cidade para se sustentar, precisa da rua como morada, precisa de andar para se manter vivo. Precisa de encontros para se potencializar.

Perder-se com instrução: uma difícil tarefa (BENJAMIN, 1997). Fazer-se andarilho é abrir mão de certezas, de mapas, de trajetos prontos. Quando se troca o mapa pela experiência é necessário disposição, percepção para o campo de forças que se apresenta: "tal disponibilidade requer um corpo sensivelmente atento e não apenas racionalmente atento aos encontros urbanos" (KNIJNIK; GUIZZO, 2012: 174).

Para conhecer a cidade, é importante perder-se. Porém, como alguém que se perde em uma floresta, é importante instrução. É importante bússola para não naufragar, para colher rastros e restos. Colher conchas. Somente quem anda pode encontrar presentes, surpresas, marcas. Encontrar o que não se procura, se encontrar. E não é sobre andar em diferentes caminhos, mas é andar de diferentes formas, com diferentes cheiros, em diferentes temperaturas, com diferentes companhias. É a mesma parede, é a mesma praça, é o mesmo asfalto, só que não é o mesmo, nunca é. A rua abre a novas possibilidades, a novos encontros, a novas afetações.

A rua vira habitual e torna-se moradia - andar na rua é sentir-se em casa. Os pixos, os letreiros tornam-se enfeite, os bancos da praça como sofás de casa, os esbarros na calçada como encontro com vizinhos: "que a vida em toda a sua diversidade, em sua inesgotável riqueza de variações, só se desenvolva entre os paralelepípedos cinzentos" (BENJAMIN, 1997: 35). Riqueza na rua, potência dos encontros. 
A cidade, as ruas, os paralelepípedos ou asfalto desacomodam, desestabilizam e convocam. Revelam o casual e o surpreendem. Desfazem planos, desfazem certezas, desfazem combinados. Tudo é provisório, tudo é imediato, tudo é possível. Afeta o corpo sensível, vira parte do próprio corpo. Sentir-se caminho. Caminhar: "Ventoárvore-ruína-passo. Vida-morte-passo. Murmúrio-silêncio-lembranças-passo" (CARVALHO; GARAVELO; ZANON, 2010: 181).

A rua é caminho: "passeio como ato, como política, como experimentação, como vida" (DELEUZE, 1998: 25). Nossos passos são acompanhados de moradores que em sua maioria tiveram como marca a rua, eram andarilhos, na rua se construíram, se constituíram. Na rua viveram grande parte da sua história. Os fragmentos aqui colhidos tiveram a rua como paisagem, como figura e como fundo. A rua que era a casa, hoje é algo que requer esforço, que requer disposição e disponibilidade, que sinaliza medo e insegurança.

\section{Atire-me ao mar: Mar de gente ${ }^{1}$}

Essa história começa lá em Portugal, terra distante de muita pobreza e improdutividade, com um menino franzino que em sua memória ficou marcado o pai bebendo e a mãe gritando por socorro. O número de irmãos já não se recorda, perdeu memórias e rompeu vínculos. Com 25 anos recebeu um convite e em um avião capenga cruzou mares, pois viu São Paulo como possibilidade. Mas não foi... O que encontrou foi mais miséria e sofrimento. Virou andarilho e ficou 25 anos a desbravar a pobreza humana de norte a sul dessa imensa terra, muito viu, muito sofreu, muito se esqueceu. Nos alerta que essa história não tem humor tampouco romance...

$$
* * *
$$

Se prefere a rua ou um teto no hospício? Prefere a rua. Na rua quase não passa fome, sempre se vira e ainda pode ver os passarinhos a cantarem pela manhã. Aliás, os pássaros são seus únicos amigos - o pessoal da rua é muito estranho. Aprendeu a conversar com jeito e assim nunca passou por uma batida policial. Como estava sempre só, ele não era alvo da polícia, não representava perigo. Inclusive os policiais em uma de suas andanças lhe apelidaram: Mendicampo. Na rua não criou vínculos, não teve família. Os mais próximos são os grandes filósofos que pegava na lixeira e serviram-lhe de companhia nos becos e nas noites frias. Conversamos sobre Schoppenhauer, sobre 
Nietzsche, e me pede um livro de Kant que começou a ler há uns anos atrás: A crítica da razão pura.

Sobre romances não tem nenhuma história para contar, foi quase um padre, mulher mesmo só viu ao longe.

Meu nome na verdade não é Jorge ${ }^{2}$. Esse nome me deram lá no hospital, me chamavam de Jorge de Tal. Não sei por que. Eles eram todos loucos. Essa data de nascimento também não é minha. Nasci no dia 24 de abril. Eles sempre faziam essas coisas... Tudo doido. Durante 11 anos que passei lá dento eu vi de tudo. Começamos até a duvidar da nossa identidade. Com nome diferente é bem difícil alguém achar, difícil.

$* * *$

Nunca teve uma companheira, nenhuma aceitava o compromisso com ele, até que tentou, mas deve ser o destino que não quis. Não conseguiu ter criança, não teve casa, não teve família, só a rua mesmo. A rua é mais fácil de lidar, só correr quando vê polícia, porque se ficar leva um furo nas costas e um na frente. Mulher é muito complicado. Aprendeu que casamento é como um cavalo com cabresto. Coloca uma corda na boca e quando precisa é só puxar a corda que o passo é interrompido. Tem que ter limite.

Meu pai morreu de câncer. Câncer de cansado.

$$
* * *
$$

Uma vida com tantas histórias truncadas e fragmentadas quando o discurso que a conta. Filho de pais humildes e adotivos, largou a escola na $7^{\mathrm{a}}$ série por não ter condições de comprar livros. Não é à toa que hoje não larga a literatura: já leu centenas deles. Em suas várias e várias viagens a pé pelo Brasil, trabalhou com o que apareceu: foi marinheiro, barman, garçom, pedreiro, vendedor, escavador, ajudante de topografia, agricultor, ufa... Andou, trabalhou, lutou e sofreu. A vida amorosa? Xi, complicado demais... Morou com uma senhora que o acolheu, viveram e batalharam juntos apesar 
do desapoio dos filhos dela. Dele só um que ficou com a mãe em Vila Velha, mas essa história melhor desconversar... Contato só através de aerograma com a família - era mais barato! Até que um dia enquanto catava papelão para vender e ter dinheiro para comprar o que comer, um conhecido deputado que diz lutar contra a pedofilia o pegou na rua e o levou para o Santa Isabel... Pronto! Agora a cidade está mais limpa! E assim sua história muda de rumo...

$$
* * *
$$

Namoro com a morte.

Sou Católico Apostólico Brasileiro. Romano não, não sou da Itália.

Meu sonho era ser jogador de bola, mas tinha que trabalhar. Parei até de estudar. Só fui até a $7^{\text {a }}$ série ginasial. Um dia quando vi que não dava mais, peguei minha bola, coloquei na sacola e fui lá no alto do convento. Furei a bola e deixei atrás da Santa, aí virei Aprendiz de Marinheiro. Deu certo só por um tempo, pois era muita água a ser desbravada, e água me enjoa, o balanço me entorpece, vomitava no balanço do mar. Preferia a beira.

\section{$* * *$}

Tive que amputar esse dedo. Coloquei um rolo de rolimã para enfeitar, ficar bonito, sabe? Igual esses jogadores que usam brinco. Só que machucou, inflamou e amputaram. Amputam o que não presta. Retiram. Limpam.

$$
* * *
$$

Nasceu em Brotas, uma cidadezinha no interior de São Paulo. A mãe trabalhava na plantação de cana de açúcar. Plantava, colhia e fazia o carregamento do caminhão. $\mathrm{O}$ pai D. Pedro, trabalhava com uma fábrica de cimento. Essa fábrica cresceu muito e tem várias filiais, inclusive eu deveria ter reparado uma na subida para Cariacica. Ah sim, não vi porque vim pelo Espírito Santo e não por Paris. Seu pai continua vivo e a trabalhar. Comprou bilhões em caminhões e está acabando de pagar. Deve faltar só uns 
dois mil. Ele mesmo trabalhava na construção de ônibus e no conserto de relógios. Já construiu dois ônibus para o Frank Sinatra e consertou vários relógios para Clotilde. Inclusive já trabalhou em Paris, a Paris que fica nos Estados Unidos. Juntava dinheiro do seu labor e repassava para o Roberto Carlos, e ele comprava os itens de higiene e alimentação para o hospital. Quando fechou vieram todos os moradores para Cariacica. Essa região tem sete casas, todas são do Roberto Carlos. Ele continua mantendo com o dinheiro que lhe é repassado. Ele sai de sua fazenda, vizinha da fazenda do Frank Sinatra, paga fiança e passa aqui na frente da casa com um carrão preto. Não para por aqui, é muito ocupado. Os mantimentos ele envia por meio do caminhão do mercado.

Menino negro lá do interior que chamava os amigos para ir pescar no rio ou na lagoa. Iam cavalgando pelas ruas de Brotas, pegavam o barquinho e sem pressa ficavam todo o dia a pescar. Pegavam lambari e tilápia. Cavalgar era terapêutico, dizia ele, podia pegar vento no rosto, os pensamentos se refrescam e sossegam. E quando dava tempo também nadava. Nadar também o fazia relaxar. Eram momentos que ele não precisava pensar em nada, a cabeça parava e o corpo estava em movimento. Movimento. Falando nisso, em dois meses ele contou 150 mil passos ao redor da quadra. Ia todas as manhãs após o café dar, literalmente, voltas na quadra. Mas agora resolveu dar um tempo, afinal, as crianças também querem usar a quadra e fica difícil com uma pessoa rodando lá dentro... Vai aderir apenas às caminhadas pela rua, sozinho. Sempre.

É a natureza que estava comigo. Só precisava de água, pedra para por a cabeça e uma grama verde. Tem que confiar na natureza.

Já alimentei todos os animais, todos os animais. Já alimentei peixe, pato, cachorro, gato. Gato não fala, não mia se não tiver alimentado. Eu também não. Pegava comida no lixo, tirava a parte podre e dava a metade para os animais. Eles são da natureza, da natureza. Tem que fazer a nossa parte, sabe? A natureza é tudo. 
Eu dividia a carne com os urubus, na verdade, na verdade, não a carne. Eu comi mesmo eram os ossos, até osso de gente.

$* * *$

Fui morar nas ruas depois que minha mãe morreu. Meu pai foi preso porque minha irmã foi estuprada e meu irmão já estava no presídio. Meu pai não aceitava que eu era bicha, tentei falar, mas ele não ouvia. Até que ele encontrou minhas calcinhas embaixo da cama. E aí já viu...

Nasci na beira da praia, sou bicha do mar.

$* * *$

Nascido e criado em Juiz de Fora, tinha apenas um irmão. Quando a família toda faleceu, resolveu andar por aí. Foi conhecer Atílio Vivacqua, só que o passeio não foi exatamente como esperado... Estava sem dinheiro, não conseguiu seus bicos de servente de pedreiro e resolveu então pedir. Só que o pedido também não foi atendido como esperado. Recebeu sim alguma comida, mas em compensação, ganhou grades, ganhou aprisionamento, recebeu um pátio para perambular. Recebeu silêncio, recebeu remédio. Conquistou um prato de comida, mas ainda tinha fome: tinha fome de falar, tinha fome de ser escutado. Tinha sede de Fanta. Passos lentos, olhar para o chão, braços jogados, voz bem baixa. Recebemos um aviso: "Conversa com ele não, que é perda de tempo, não da para escutá-lo". Minha resposta? Um olhar. Um olhar que se fez entender. A resposta foi a quem interessava ao pé do ouvido: "nos entendemos muito bem, não é?" Um sorriso me abraçou.

\section{Referências}

BAPTISTA, Luis Antonio; SILVA, Rodrigo LAGES. A cidade dos anjos do improrrogável. Rev. Polis e Psique, p. 49-73. 2017.

BARÃO VERMELHO. Maior Abandonado. Maior Abandonado. Por CAZUZA, 1984.

BARTHES, Roland. Roland Barthes por Roland Barthes. São Paulo: Editora Cultrix, 1977

BENJAMIN, Walter. Obras escolhidas II: rua de mão única. São Paulo: Brasiliense, 1995. 
BENJAMIN, Walter. Obras Escolhidas III - Charles Baudelaire: um lírico na época do capitalismo. São Paulo: Brasiliense, 1997.

CARVALHO, Julia Dutra; GARAVELO, Leonardo Martins Costa; ZANON, Regina Basso. S/t: silêncios e testemunhos. In: COSTA, Luciano Bedin; FONSECA, Tania Mara Galli (Org.). Vidas do fora: habitantes do silêncio. Porto Alegre: Editora da UFRGS, 2010, p. 47- 69.

COSTA, Luciano Bedin. O destino não pode esperar ou o que dizer de uma vida. In: COSTA, Luciano Bedin; FONSECA, Tania Mara Galli (Org.). Vidas do fora: habitantes do silêncio. Porto Alegre: Editora da UFRGS, 2010, p. 47- 69.

DELEUZE, Gilles; PARNET, Claire. Uma conversa, o que é, para que serve? In: DELEUZE, G.; PARNET, C. Diálogos. São Paulo: Escuta, 1998.

FOUCAULT, M. O poder psiquiátrico: curso dado no Collège de France (1973-1974). São Paulo: Martins Fontes, 2006.

GROS, Frédéric. Caminhar, uma filosofia. São Paulo: É Realizações, 2010.

KNIJNIK, Cristiane; GUIZZO, Iazana. Troca de segredos: um dispositivo que contagia experiências. In: BAPTISTA, Luis Antonio; FERREIRA, Marcelo Santana (orgs). Por que a cidade? Escritos sobre experiência urbana e subjetividade. Rio de Janeiro: Eduff, 2012, p. 31- 52.

MIZOGUCHI, Danichi Hausen. Equivocidades. In: BAPTISTA, Luis Antonio; FERREIRA, Marcelo Santana (Org.). Por que a cidade? Escritos sobre experiência urbana e subjetividade. Rio de Janeiro: Eduff, 2012, p. 53- 64.

O RAPPA. Mar de gente. Por FARIAS, Lauro; FALCÃO, Marcelo; LOBATO, Marcelo; XANDÃO. 2003.

PELBART, Peter Pál. A vertigem por um fio: políticas da subjetividade contemporânea. São Paulo: Iluminuras, 2000.

SILVA, A. S. A Emergência do Acompanhamento Terapêutico: O Processo de Constituição de uma Clínica. Instituto de Psicologia Universidade Federal do Rio Grande do Sul, 2005.

M. ${ }^{a}$ Kamila Vilela de Souza Universidade Federal do Espírito Santo E-mail: kamila.vilela@hotmail.com

Prof. ${ }^{a}$ Dr. ${ }^{a}$ Leila A. Domingues Machado

Universidade Federal do Espírito Santo

E-mail: leila.liscnpq@gmail.com

\footnotetext{
${ }^{1}$ O RAPPA. Mar de gente. Por FARIAS, Lauro; FALCÃO, Marcelo; LOBATO, Marcelo; XANDÃO. 2003.

${ }^{2}$ Nome fictício
} 